\title{
Editorial \\ Mercury and Methylmercury Contamination of Terrestrial and Aquatic Ecosystems
}

\author{
Stéphane Guédron $1, *\left(\right.$ i) and Dario Acha ${ }^{2, *(1)}$ \\ 1 Geochemistry Department, Institut des Sciences de la Terre (ISTerre), University Grenoble Alpes, \\ University Savoie Mont Blanc, CNRS, IRD, IFSTTAR, 38000 Grenoble, France \\ 2 Unidad de Calidad Ambiental (UCA)—Instituto de Ecología_-Universidad Mayor de San Andrés, \\ Campus Universitario de Cota Cota, Casilla, La Paz 3161, Bolivia \\ * Correspondence: stephane.guedron@ird.fr (S.G.); darioacha@yahoo.ca (D.A.)
}

check for updates

Citation: Guédron, S.; Acha, D. Mercury and Methylmercury Contamination of Terrestrial and Aquatic Ecosystems. Appl. Sci. 2021, 11, 4807. https://doi.org/10.3390/ app11114807

Received: 14 April 2021

Accepted: 17 May 2021

Published: 24 May 2021

Publisher's Note: MDPI stays neutral with regard to jurisdictional claims in published maps and institutional affiliations.

Copyright: (c) 2021 by the authors. Licensee MDPI, Basel, Switzerland. This article is an open access article distributed under the terms and conditions of the Creative Commons Attribution (CC BY) license (https:// creativecommons.org/licenses/by/ $4.0 /)$.
In 2017, 128 countries signed the Minamata Convention on Mercury $(\mathrm{Hg})$ to protect human health and the environment from the adverse effects of mercury. Although $\mathrm{Hg}$ naturally occurs at a global scale, anthropogenic releases of $\mathrm{Hg}$ affect its natural biogeochemical cycle. Since the industrial revolution, anthropogenic pressure and $\mathrm{Hg}$ contamination have risen, affecting natural ecosystems (e.g., lake eutrophication, deforestation, mining, and climate change) and urban areas (wastewaters, atmospheric emissions, and industrial discharges). Consequently, it has resulted in a general increase in $\mathrm{Hg}$ levels in all components of ecosystems, particularly in $\mathrm{Hg}$ bioaccumulation in trophic chains, mostly as methylmercury $(\mathrm{MeHg})$. However, $\mathrm{Hg}$ and $\mathrm{MeHg}$ impacts are dependent on a large variety of abiotic and biotic factors with complex interactions among them, which often results in locally specific responses that we are still trying to understand.

Identifying sources, magnitude, pathways, and mechanisms of $\mathrm{Hg}$ and $\mathrm{MeHg}$ contamination in terrestrial and aquatic environments is crucial to determine and predict future impacts of this contaminant in the environment. It is also difficult to predict the risks and the $\mathrm{Hg}$ toxicity for wildlife and humans. The identification of processes driving $\mathrm{Hg}$ release from current and historical sources, key transformations (i.e., methylation/demethylation), and $\mathrm{Hg}$ accumulation in terrestrial and aquatic ecosystem is still challenging to assess. These interconnected processes can affect both natural (temperate and extreme) and anthropogenic (urban, agricultural, and mining) areas at various spatial and temporal scales.

Nine articles were accepted following the October 2019 call for a Special Issue (SI) on "Mercury and Methylmercury Contamination of Terrestrial and Aquatic Ecosystems", announced at the 14th International Conference on Mercury as a Global Pollutant-Krakow, Poland (8-13 September 2019). They present a diverse but coherent collection that endeavors to identify the historical evolution of $\mathrm{Hg}$ and $\mathrm{MeHg}$ levels in aquatic environments and to evaluate the impact of human activities, in particular mining, on receptor ecosystems and food chains.

The need to evaluate the evolution of mercury and methylmercury contamination from historical to modern times is a key to assessing the impact of global regulations and to predicting future trends. Various approaches are presented in this SI, including fossils or modern organisms as bioindicators of trophic contamination. Using Hg levels in the hair of prehistorical animals, Eyrikh et al. [1] showed the first evidence of natural changes in environmental $\mathrm{Hg}$ level at the paleoscale (45 to $10 \mathrm{ka} \mathrm{yr} \mathrm{BP)} \mathrm{suggested} \mathrm{to}$ be driven by high dust loads in cold periods and thawing permafrost in warm climatic periods. Cossa and Tabard [2] used marine mussels (Mytilus spp.) as sentinel organisms to monitor $\mathrm{Hg}$ contamination along the Canadian marine coast for the past 40 years. They show that, despite a decrease in $\mathrm{Hg}$ concentrations in the Atlantic Ocean's marine waters during the last decades, the difference in two mussels watch surveys between 2016-2019 and 1977-1979 were not significant. Consequently, they suggest rivers as the main $\mathrm{Hg}$ 
source in such estuarine systems. In contrast, in the United States and Canadian Lakes, Brigham et al. [3] showed that regional- to continental-scale decreases in both mercury and sulfate emissions have benefitted aquatic resources, even in the face of global increases in mercury emissions. In long-term biomonitoring of three lakes, the authors found a decline in aqueous $\mathrm{MeHg}$, whereas biotic $\mathrm{THg}$ concentrations declined significantly in only one lake. Overall, these studies also show the complexity and mosaic-like characteristics of $\mathrm{Hg}$ pollution at the regional to the global scales, underling the need for further local research and tools to understand the global picture better.

Simultaneously monitoring MeHg pollution and its potential toxicity to biota also remains a significant challenge. Evaluating the stress of local biota related to $\mathrm{MeHg}$ requires a complex analysis of bioavailability, bioaccumulation, biomagnification, and physiological characteristics of organisms. Even doing this makes it difficult to establish a clear relation between $\mathrm{MeHg}$ concentrations and any negative effect on biota. Furthermore, it is challenging to assess $\mathrm{MeHg}$ toxicity in the frequent presence of other co-occurring stressors with the potential for synergic or antagonist effects. Ecotoxicological studies offer feasible alternatives to address this complex issue. A good example is how the toxicity of methylmercury to loggerhead turtles was evaluated by Hernández-Fernández et al. [4] using the activity of the enzymes superoxide dismutase (SOD), glutathione S-transferase (GST), and lipid peroxidation by malondialdehyde (MDA) as biomarkers of environmental pollution and oxidative stress.

Another major issue in the anthropogenic perturbation of the $\mathrm{Hg}$ biogeochemical cycle is assessing the impact of historical and current gold mining activities. Historical mining activities are still sources of $\mathrm{Hg}$ for downstream ecosystems. Samaniego et al. [5] show evidence of the persistent contamination of abandoned and inactive mines in the Philippines, even 50 to 70 years later, releasing high amounts of $\mathrm{Hg}$ into riverine and marine environments. In current alluvial gold mines of the Amazon region, Guzmán-Uria et al. [6] highlight the impact of soil degradation on the $\mathrm{Hg}$ release into downstream hydrosystems. Hellal et al. [7] demonstrate that particulate $\mathrm{Hg}$ and $\mathrm{MeHg}$ transport rises downstream from gold mine sites, with the highest emissions during high water regimes (rainy season). In contrast, the highest releases of dissolved $\mathrm{MeHg}$ (up to $30 \%$ of $\mathrm{THg}$ ) occur mainly during low water regimes. In downstream receptacle aquatic ecosystems, the methylation of accumulated $\mathrm{Hg}$ is generally enhanced. Guédron et al. [8] show that, in mine-impacted high-altitude aquatic ecosystems of the Andes, the production and release of $\mathrm{MeHg}$ is driven by sediment effluxes to the water column and diel redox oscillations. Finally, they highlight that, although MMHg loading from the PW to the SW is large, $\mathrm{MMHg}$ photodegradation and demethylation by microorganisms control net $\mathrm{MMHg}$ accumulation in the water column.

These studies converge toward the idea that, even though $\mathrm{Hg}$ is banned, current gold-mining practices still release natural $\mathrm{Hg}$ that, added to the $\mathrm{Hg}$ inherited from older and modern mining practices, impact downstream ecosystems. The improvement of mining practices is thus key to regulating and mitigating these $\mathrm{Hg}$ emissions. Indeed, Couic et al. [9] demonstrate that recent rehabilitation efforts in French Guyana's mining sites show promising results that depend on the type of ecological rehabilitation protocols. They demonstrate that specific plant species (e.g., fabaceous species) positively affect soil quality that can significantly reduce mercury mobility and toxicity.

\section{References}

1. Eyrikh, S.; Boeskorov, G.; Serykh, T.; Shchelchkova, M.; Papina, T. Mercury in Hair of Mammoth and Other Prehistorical Mammals as a Proxy of Hg Level in the Environment Associated with Climate Changes. Appl. Sci. 2020, 10, 8664. [CrossRef]

2. Cossa, D.; Tabard, A.-M. Mercury in Marine Mussels from the St. Lawrence Estuary and Gulf (Canada): A Mussel Watch Survey Revisited after 40 Years. Appl. Sci. 2020, 10, 7556. [CrossRef]

3. Brigham, M.E.; VanderMeulen, D.D.; Eagles-Smith, C.A.; Krabbenhoft, D.P;; Maki, R.P.; DeWild, J.F. Long-Term Trends in Regional Wet Mercury Deposition and Lacustrine Mercury Concentrations in Four Lakes in Voyageurs National Park. Appl. Sci. 2021, 11, 1879. [CrossRef] 
4. Hernández-Fernández, J.; López-Barrera, E.A.; Mariño-Ramírez, L.; Rodríguez-Becerra, P.; Pinzón-Velasco, A. Oxidative Stress Biomarkers in Erythrocytes of Captive Pre-Juvenile Loggerhead Turtles Following Acute Exposure to Methylmercury. Appl. Sci. 2020, 10, 3602. [CrossRef]

5. Samaniego, J.; Gibaga, C.R.; Tanciongco, A.; Rastrullo, R. Total Mercury in Soils and Sediments in the Vicinity of Abandoned Mercury Mine Area in Puerto Princesa City, Philippines. Appl. Sci. 2020, 10, 4599. [CrossRef]

6. Guzmán-Uria, F.; Morales-Belpaire, I.; Achá, D.; Pouilly, M. Particulate Mercury and Particulate Organic Matter in the Itenez Basin (Bolivia). Appl. Sci. 2020, 10, 8407. [CrossRef]

7. Hellal, J.; Schäfer, J.; Vigouroux, R.; Lanceleur, L.; Laperche, V. Impact of Old and Recent Gold Mining Sites on Mercury Fluxes in Suspended Particulate Matter, Water and Sediment in French Guiana. Appl. Sci. 2020, 10, 7829. [CrossRef]

8. Guédron, S.; Achá, D.; Bouchet, S.; Point, D.; Tessier, E.; Heredia, C.; Rocha-Lupa, S.; Fernandez-Saavedra, P.; Flores, M.; Bureau, S. Accumulation of Methylmercury in the High-Altitude Lake Uru Uru (3686 m asl, Bolivia) Controlled by Sediment Efflux and Photodegradation. Appl. Sci. 2020, 10, 7936. [CrossRef]

9. Couic, E.; Alphonse, V.; Livet, A.; Giusti-Miller, S.; Bousserrhine, N. Influence of Ecological Restoration on Mercury Mobility and Microbial Activities on Former Guyanese Mining Sites. Appl. Sci. 2021, 11, 2231. [CrossRef] 